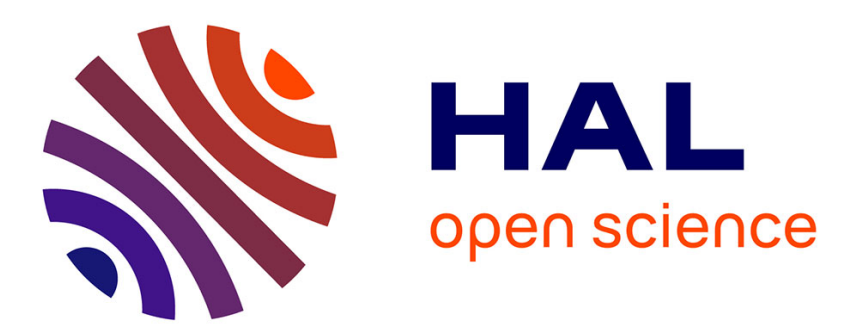

\title{
Contextualising learning through the participatory construction of an environmental education programme
}

Isabel Ruiz-Mallen, Laura Barraza, Barbara Bodenhorn, Maria de La Paz

Ceja-Adame, Victoria Reyes-García

\section{- To cite this version:}

Isabel Ruiz-Mallen, Laura Barraza, Barbara Bodenhorn, Maria de La Paz Ceja-Adame, Victoria Reyes-García. Contextualising learning through the participatory construction of an environmental education programme. International Journal of Science Education, 2009, 32 (13), pp.1755. 10.1080/09500690903203135 . hal-00520361

\section{HAL Id: hal-00520361 \\ https://hal.science/hal-00520361}

Submitted on 23 Sep 2010

HAL is a multi-disciplinary open access archive for the deposit and dissemination of scientific research documents, whether they are published or not. The documents may come from teaching and research institutions in France or abroad, or from public or private research centers.
L'archive ouverte pluridisciplinaire HAL, est destinée au dépôt et à la diffusion de documents scientifiques de niveau recherche, publiés ou non, émanant des établissements d'enseignement et de recherche français ou étrangers, des laboratoires publics ou privés. 


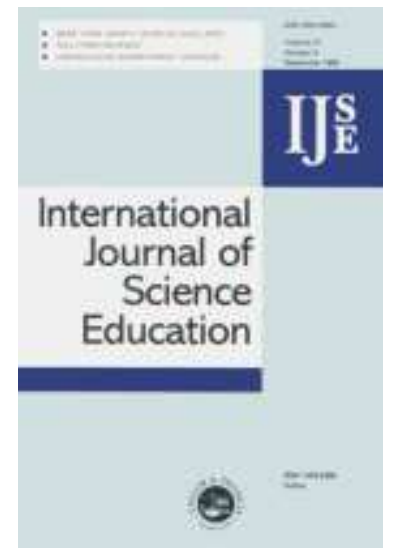

\section{Contextualising learning through the participatory construction of an environmental education programme}

\begin{tabular}{|r|l|}
\hline Journal: & International Journal of Science Education \\
\hline Manuscript ID: & TSED-2008-0370.R3 \\
\hline Manuscript Type: & Research Paper \\
\hline Keywords: & action research, environmental education \\
\hline Keywords (user): & $\begin{array}{l}\text { contextualising as pedagogical technique, Mexico, participatory } \\
\text { methods }\end{array}$ \\
\hline
\end{tabular}

\section{$\checkmark$ ScholaroNE \\ Manuscript Central}




\title{
CONTEXTUALISING LEARNING THROUGH THE PARTICIPATORY CONSTRUCTION OF AN ENVIRONMENTAL EDUCATION PROGRAMME
}

\begin{abstract}
Strengthening links between school and community is critical for improving people's participation in environmental issues. However, Mexican education programmes are generally unrelated to rural students' life experience and are planned without considering either teachers' or students' opinions. This paper describes the participatory construction of a preparatory school environmental education programme in Ixtlan de Juarez, a Mexican indigenous community internationally recognized for sustainable forest management. The qualitative research methods used are based on the action research methodology. Results from interviews conducted with the preparatory school's headmaster, the coordinator, and nine teachers provided the needed documentation of the school site for contextualising learning activities. Feedback during focus group with six students, three teachers, five local communal authorities, and two researchers highlighted that all participants perceived the need for creating an educational programme focused on local forest management. The contents and activities of the programme were designed by the focus group's participants. The programme has been continuously taught by teachers and forest workers since 2005 and was officially integrated with the preparatory school science curriculum in 2006. This participative educational experience has thus transformed the mandatory school curriculum in Ixtlan.
\end{abstract}

KEYWORDS: action research, contextualising as pedagogical technique, environmental education, Mexico, participatory methods. 


\section{Introduction}

Environmental education researchers consider that environmental education (EE) ideally should be a nodal component of education. EE should not be a fashion, but a fundamental dimension of contemporary education because it has the capacity to provide the basis for the reconstruction of relationships amongst persons, societies, and the environment (Sauvé, 1999). In developing countries many attempts have been made to incorporate EE into school curriculum. These efforts have frequently focused on the concept of contextualisation through active learning, a concept that refers to a strategy for curriculum development based on the school's local context (UNESCO, 1994). Unfortunately, most of those attempts have only resulted in the introduction of some local topics and activities into the school curriculum (Taylor \& Mulhall, 2001), mainly as part of the natural sciences' school subject. As a consequence, the incorporation of EE in formal education is a pending matter in developing countries.

The present article describes the construction of a preparatory school EE programme in Ixtlan de Juarez in Oaxaca, a Mexican indigenous community located in the pine forests of Sierra Norte. The EE programme was and continues to be focused on forest management which is particularly relevant for a community economically dependent on forest resources. Ixtlan is representative of other indigenous communities in Mexico, where around $80 \%$ of the national forest resources are held by such groups (Snook, 1997), but it is also exceptional because is among the few indigenous communities in Mexico that have successfully managed their forest in both biologically and economically sustainable ways over decades. Ixtlan's experience in forest management shows that community-owned forestry enterprises can have a positive role in conserving biodiversity. However, the permanence and growth of such successful experiences depend on adolescents' professional future interests in their community.

Our research in the area (Ruiz-Mallén, Barraza, Bodenhorn, \& Reyes-Garcia, 2009) 
suggests that preparatory school students have a low knowledge on ecological issues included in the school curriculum. For instance, results from a questionnaire on ecological concepts taught at school showed that only 43 of 95 students knew the meaning of the term "silviculture", which is centrally related to their local environment because of the forest management activities in Ixtlan. We have argued that the low knowledge of ecological concepts might be due to the passive methods used to teach school science concepts, since previous research suggests that passive methods do not promote students' enduring interest in school ecological and environmental learning (Barraza, 2000; Reinfried, 2004). To promote students' interest in science, participatory research projects should be actively linked to community concerns. Otherwise, if adolescents do not develop an interest in environmental issues, it is likely that the successful forestry enterprise can not survive. In such communities, the school can and should act as a bridge between the final stage of formal schooling and local natural resource management to enable the continuity and success of community-owned forestry enterprises (see also Ruiz-Mallén \& Barraza, 2006).

To address the challenge, we conducted this research with the aim of promoting relationships between environmental and ecological school contents and local forestry issues in the Ixtlan preparatory school curriculum. To do so we relied on the EE research model proposed by Barraza (2000), the fundamental principle of which is that the final education proposal must be a result of a contextualised and participatory research process. Two information-gathering steps were considered for constructing a contextualised EE programme. First, semi-structured interviews were conducted with preparatory school teachers to document the study site for the contextualisation of the school programme. Second, a focus group with students, teachers, and local authorities from Ixtlan was conducted to plan an education programme focused on forest management. Information from semi-structured interviews was useful for directing the discussion of the focus group and for reaching consensus about the need to create an EE programme focused 
on forest management. The EE programme has been self-conducted by preparatory school teachers and community forestry workers since 2005 .

The description of this case study is important for two reasons. First, it improves our understanding of key issues on contextualising learning, such as how to design contents and activities in an EE programme, or how to motivate people to participate in decisions about programme's contents and activities. The description of this case study is also important to assess potential implications for planning EE in indigenous communities involved in forestry. Preparatory schools from other indigenous communities can take advantage of the EE experience presented here by adapting the Ixtlan programme to address their possibilities, needs, and interests. Given that the director of the preparatory school system for the State of Oaxaca incorporated the forestry education programme discussed here as a part of the Ixtlan's preparatory school curriculum, this article describes an experience that represents an important step in the official recognition of the need to incorporate more local environmental topics in the Mexican preparatory school science curriculum.

\section{Action research for planning participatory EE programmes}

EE researchers recognise that the positivist/scientific research paradigm, characterised by the use of quantitative methods for measuring the acquisition of environmental knowledge, originally dominated the relatively young and evolving field of EE (Palmer, 1998). More recently, within the rapidly expanding research in EE, two additional paradigms have appeared as a reaction to the positivist paradigm. The two paradigms [interpretativism/constructivism and critical theory/action research] have very different underlying assumptions (Hart \& Nolan, 1999; Palmer, 1998). Together, the three main paradigms within EE research are employed to explain people's behaviour related to their environment and attempt to control this behaviour by 
promoting attitudinal change. Differences between the theoretical and methodological foundations of these paradigms can be understood through the questions asked by each of them. Positivists ask "how many" or "how much" environmental knowledge, perceptions or attitudes do people acquire; interpretativists ask "how" people acquire, assimilate, or transmit environmental knowledge; and critical theorists ask "why" do people acquire environmental knowledge. Critical theorists seek useful participatory processes in the acquisition of environmental knowledge. But what does a participatory process mean in EE?

There is a tendency in the field of EE to confound participation with activism (i.e. waste separation, beaches cleaning or reforestation activities), but some authors have argued that EE cannot be reduced to activism because when the basis for practice is not clear, there is a breakdown between theory and practice (García-Ruiz \& Calixto, 2006; Sauvé, 1999). For instance, Hart (1997) argues that many environmental educators assume that EE programmes should promote some kind of direct action on behalf of the environment. Unfortunately, many environmental educators assign children and adults with tasks instead of encouraging them to identify their own problems and propose their own solutions. For EE to be effective, it should focus on the issues and worries that concern people's daily lives (Sauvé, 1999). Thus, EE should allow people to understand causes and consequences of their own environmental situation for empowering them and promoting their participation in solving local environmental problems. Based on our research in another Mexican indigenous community [San Juan Nuevo Parangaricutiro in Michoacan], elsewhere we argue that, to raise people's motivation and interest, the design of any educational activity should be based on participants' opinions (Ruiz-Mallén \& Barraza, 2006). Participation can only be achieved by developing learning methods that allow students to establish connections between their learning at school and their local problems (see also Barraza \& Ruiz-Mallén, 2007). 
The critical theory/action research framework for EE research offers a good opportunity to reduce the gap between theory and practice by involving community members in planning community-based EE content and activities. The framework uses action research to change practices by making them more consistent with the pedagogical aims or with the personal educational ideals that teachers reflexively construct to guide their actions (Elliot, 1994). According to Palmer (1998) the action research framework clearly challenges traditional pedagogy and curriculum organization, a challenge that, for a variety of reasons, few may feel able or willing to take. This framework implies the creation of new roles for and relations among students, teachers, and curriculum developers. For example, in an action research science project conducted in seven primary schools in the UK, students were engaged in data collection (i.e. hardness of kitchen surfaces, heat retention of sleeping bags) and participated in group discussions of the findings (Warwick \& Siraj-Blatchford, 2006). Results from interviews with students and teachers suggested that children were motivated to raise and address questions thrown up by the data analysis and seemed able to discuss procedural understanding in science. In another action research in Canada, Hodson and Bencze (1998) analysed how six science teachers worked with a change agent to evaluate their current educational practice and improve science classroom activities. All teachers had to learn, as they were students, how to describe their practice to the others and give criticism to their actions. Teachers' reflection on current practice culminated in deciding on, implementing, and evaluating novel science curriculum activities. In another action research in north-eastern Brazil, Watts and Jofili (1998) engaged secondary school teachers in a course on critical constructivist education in which they were required to shape individual action-research projects to be undertaken in their schools. In interviews conducted 15 months after the program ended, teachers pointed out that their educational approaches had changed in discussing concepts with students and contextualizing 
science lessons using school surrounding examples. Teachers also noted that their students discovered their role in knowledge construction and became aware that learning does not just depend on the teacher. Then the action research framework seriously challenges the status quo in subject-based curriculum, in initial teacher education and continuing professional development, and in research itself. In sum, action research integrates the processes of pedagogical transformation and theory generation (Elliot, 1994). For this reason, understanding the process of learning and teaching becomes fundamental in action research.

In this study, action research theory was put into practice. The methods were used to promote Ixtlan adults' reflection on the need to develop a formal EE programme addressed to adolescents, as well as their participation in planning its contents and activities.

\section{Learning and teaching contextualisation}

The action research framework in EE is strongly linked with the assumed value of contextualising learning and teaching. According to Duit (1991) contextualisation is based on a constructivist perspective: people learn by constructing their own knowledge as a result of their experience based on their interaction with the environment where they live. Therefore, a contextualised curriculum should be constructed by students, teachers, school authorities, and the community considering relations and interactions between people, their environment, and their culture. An action research framework in EE promotes a teaching-learning process based on the direct experience of the learners in their local environment by allowing them to achieve selfreflection and to create collaborative relations between themselves and the rest of the learning community (Kemmis \& Carr, 1988). So action research gives researchers the participatory methods for developing contextualised education programmes.

Research suggests that participation in curriculum planning results in more challenging, 
effective, and enjoyable learning (Watts \& Jofili, 1998; Ballantyne, Fien \& Packer, 2001; Taylor \& Mulhall, 2001). For example, in a comparative research in Tanzania, Sri Lanka, India, and Ethiopia, Taylor and Mulhall (2001) explored three learning environments for primary school students: school, home, and community. The research aimed to discover the role of agricultural experience as a vehicle for contextualising learning in situations where learners' life experience had been enriched by agriculture. They found that teachers attempted to contextualise learning by relating the content of the curriculum to the life experience of their students. To contextualise learning, teachers employed general examples with which students were thought to be familiar. The authors found that when the curriculum content was contextualised, children understood better, supposedly because they paid more attention knowing that this learning could be used in practice. For example, a group of students from Tanzania had difficulty grasping the meaning of the term "bunch" until they were taken outside and shown a bunch of bananas on a tree.

In other research, Ballantyne et al. (2001) used a case study approach to explore the impact of two contextualised school EE programmes in Australia. The researchers helped contextualise learning by working with three teachers, 62 parents, and 152 students in a variety of environmental issues. The authors concluded that both programmes were successful in engaging students in thinking and learning environmental issues and identified two major factors that contributed to it: 1) connecting topics taught in the programme with the interests of the group and 2) establishing more interactions between programmes' content and activities and the lives of students' parents.

Unfortunately, it is difficult to find such participatory curriculum planning experiences in Mexico, where the curriculum at primary, secondary, and preparatory school is extremely rigid (Barraza \& Waldrof, 2002). The Federal Education Ministry dictates the basic curriculum for each education level, which is the same for all the schools in the country. For example, as 
Aguilera, Rodríguez, and Silva (2006) argue the content of much curriculum design in Mexico is the same for urban and for rural schools, so curricula are not pertinent to students because they follow a non-aligned point of view. Curricular homogeneity neglects the basic principle that curriculum planning should be contextualised so that it is related to students' values, culture, life conditions, and future expectations, as well as to community economic activities (Peralta, 1996).

Despite the lack of institutional flexibility, there are a variety of EE experiences supported by several State Education Ministries, academic institutions, and non-governmental organizations. One such initiative is the EE programme called "Science in the family" from Nuevo Leon, Northern Mexico. In this programme, primary school students, parents, teachers, and researchers collaborate in raising children's sensibility to local natural resource conservation (Elizondo, Flores \& González, 2007). However, the creation of a formal EE programme in which Mexican teachers, students, and the community participate in designing content and activities is far from the Mexican education reality, more so in rural contexts. Each year, teachers are forced to complete the basic curriculum provided by the Federal Education Ministry. Teachers have neither the time nor the economic incentives to think about implementing EE programmes related to local resource management that are not included in the school curriculum. As a result, many educators just hand down knowledge employing passive teaching methods and students have no active role in the learning process (Barraza, 2001). The limitation has implications for students' learning. For instance, Barraza and Cuarón (2004) found that new science words or concepts taught to Mexican children through the use of textbooks were less likely to be understood than concepts taught through hand-on activities.

In sum, previous research suggests that it is desirable to contextualise school curriculum in the environmental learning context of the students and to promote the use of practical and participatory teaching methods. However, research also shows that contextualising learning and 
including participatory methods in the curriculum are complex issues in Mexico. The present study contributes to increase the research on contextualising learning by exploring the case of a preparatory school in a Mexican indigenous community.

\section{A Mexican community successfully involved in forest management}

The indigenous community of Ixtlan de Juarez (around 5000 inhabitants) is located in the state of Oaxaca, in the south-east of Mexico. Since 1986, Ixtlan has adopted a conservation strategy based on the sustainable management of its forests and is one of the first indigenous communities to have a communal forestry enterprise in Mexico (Ruiz-Mallén et al., 2009).

Ixtlan's internal governance is a mix of pre-colonial traditions (communal authority) and modern political systems (the municipality). The General Assembly is the supreme communal governing body that decides on all principal issues within the community as defined by common ownership of territory (Antironi \& Rausser, 2007). As required by law, during the General Assembly sessions, each registered member of the community, corresponding to comunero families (forestry enterprise owners), has one vote on decisions regarding the management of natural resources. There are 384 comunero families (Comunidad de Ixtlan de Juarez, 1999), which have preference in gaining jobs in the forestry enterprise. Enterprise workers can work in a variety of jobs (i.e. forest logger, forest management technician, sawmill or factory worker, and office administrator) depending on their aptitude, skills, and level of formal education.

In Ixtlan there is only one preparatory school where adolescents from 15 to 20 years of age are prepared for higher education at a university or college. The school belongs to the CECyTE system [Scientific and Technologic Studies Centre]. The CECyTE curriculum differs from most Mexican preparatory school curricula in that its content is not totally defined by the Federal Ministry of Education, but rather each teacher elaborates the programme for the subject 
that $\mathrm{s} /$ he teaches. A preparatory school coordinator and supervisors from the State Education Ministry review all the programmes before implementation. As a result, the CECyTE curriculum is more flexible and dynamic than most of the other Mexican preparatory school education curricula.

\section{Methods}

The present study is based on the EE research model proposed by Barraza (2000), which main axis is the participatory research understood as a social process of knowledge generation, a research model that requires interaction among all participants (including researchers) in the process (Barraza \& Ruiz-Mallén, 2007).

Data for the study were collected in 2005 and 2006. One of the authors of this article lived in the community for the entire duration of the research, which resulted in many opportunities of formal and informal interactions with all the participants of the study. Two research techniques were used with the ultimate aim of collaboratively developing an EE programme for Ixtlan preparatory school: semi-structured interviews and focus groups. The research was conducted in Spanish, which is the first language of the participants as well as of most of the researchers.

A total of 11 semi-structured interviews were conducted with the school's headmaster, the coordinator, and nine teachers randomly selected from the 20 who were working at the CECyTE at the time of the research. Random selection allowed us to work with a variety of school teachers in order to explore their perceptions of the educational setting. It also avoided a focus on predictable components (i.e. teacher's age, gender, school subject). The selected teachers taught courses in Chemistry, Math, Computer technology, Nursing, History, and Literature.

We used semi-structured interviews to explore teachers' perceptions and opinions about: 1) the degree of contextualisation in the preparatory school curriculum, 2) the inclusion of local 
forest management in the school curriculum, and 3) students' interest in local environmental issues. We structured the interviews around two topics: "Is the curriculum related to the activities of the community forestry enterprise and how?" and "Is it necessary to reinforce adolescents' knowledge on local forestry and how?" The interviews were conducted orally and consisted of 12 open-ended questions related to the two topics mentioned (Table 1). The interviewers were also able to ask further questions if they thought they could obtain additional relevant information. Data were qualitatively analysed using the grounded theory (Strauss, 1987), an inductive theory that consists in interpreting data by means of the analytical reasoning to make a theory focused on the study subjects' perception on the social phenomena. Thematic categories related to the topic aims were constructed from teachers' answers and then categories were interrelated in a network diagram (Figure 1).

\section{INSERT TABLE 1 ABOUT HERE}

After analyzing results from semi-structured interviews, we conducted a focus group to create a proposal for an EE programme. Focus groups provide an opportunity for discussing and planning a programme cooperatively by talking with several people at once. According to Gayford (1993) group discussion-based learning has a motivating effect on students and is an effective method of providing students with the opportunity to develop learning skills on EE.

We invited preparatory school teachers to participate in the focus group, as well as school and other communal authorities. From the 20 teachers and 11 representatives invited, eight of them voluntarily agreed to participate in this research activity. Additionally, we asked teachers to indicate the name of the students who would be willing to participate. The list consisted of six potential students, all of whom were invited and all of whom voluntarily agreed to participate. Overall, 16 people participated in this research activity. They included: six preparatory school students and three teachers with an interest in teaching environmental issues, three 
representatives from both the municipal and communal authorities as well as two from forestry and ecotourism enterprises, and two researchers. For two hours participants discussed the need to contextualise the CECyTE curriculum in relation to community forestry policies and activities. The focus group started with a group discussion on the following question: How a preparatory school EE programme should be planned? The researchers used the case of another Mexican indigenous community involved in forestry [San Juan Nuevo Parangaricutiro], which had just developed a cooperative EE programme between its preparatory school and its communal forestry enterprise (Barraza \& Ruiz-Mallén, 2007), to provide an example of how an EE programme could be built.

\section{Results}

\section{Teachers' semi-structured interviews: Curriculum contextualisation}

The results of the analysis of semi-structured interviews are organized in a network diagram of theme categories (Figure 1). The network diagram describes teachers' opinions on the current inclusion of local and environmental topics in the preparatory school curriculum and their proposals for improving the provision of school-based EE in the community.

\section{INSERT FIGURE 1 ABOUT HERE}

Teachers explained that environmental topics were part of the current Ixtlan CECyTE curriculum in the $1^{\text {st }}$ and $2^{\text {nd }}$ years. Students in the $3^{\text {rd }}$ year had the opportunity to choose between two areas of expertise: Nursing or Computer technology, but did not have an option related with environmental issues.

The majority of teachers explained that they did not deal with local and environmental issues in their classes because these topics were not included in the curriculum: 
'Preparatory school curriculum is very general. There is not a subject focused on environmental issues. I think they should be included in the preparatory school curriculum' [Literature teacher].

Faced with this gap in environmental contents, teachers proposed several solutions to contextualise curriculum in relation to local natural resource management. Six teachers proposed to develop an area of expertise on forest management for the local CECyTE school curriculum. Furthermore, all of the teachers mentioned that it was necessary to do more EE activities as a part of the regular curriculum. They agreed that students should know about the activities of the communal forestry enterprise and be more aware of the importance of Ixtlan forest management for environmental conservation:

'It is necessary to include subjects on environmental science. For this reason, I mentioned before an area of expertise in forest management' [Literature teacher].

'We could learn about the enterprise's activities and inform the rest of the community about it, and motivate their interest in it by creating a link between the school and the forestry initiatives' [Chemistry teacher].

'There could be lectures, guide visits, and films about the destruction of our environment. We are not so far from the city of Oaxaca where they [Oaxaca's population] are losing everything [their natural resources]. We still are lucky because we have forests' [Computer teacher].

Teachers felt confident that communal authorities would support school EE activities because, in general, Ixtlan's population was concerned with environmental conservation and there was a precedent of institutional cooperation between the school and the community. 


\section{Focus group: Participatory planning of the EE programme}

The most important result from teachers' semi-structured interviews related to the need to promote curriculum contextualisation. Thus the focus group already mentioned was organised to present to the local authorities these results and to discuss collectively the necessity of creating an EE programme focused on forest management. Under the suggestion of researchers, the focus group agreed to develop a participation-action education process based on the participants' reflection about the need to include more local and environmental topics in the preparatory school curriculum.

During the focus group, researchers noticed that students agreed with their teachers on the importance of contextualising learning. Students said that they would like to learn more about the social, political, natural, and economic issues of the community. Students requested field trips to the forest and to the communal forestry enterprise. Local authorities also agree with students and teachers and pointed out the need to transmit local environmental knowledge and values to new generations. They mentioned that the best way to achieve the transmission of local environmental knowledge was providing students the possibility of observing and experiencing how the community manages its natural resources. Local authorities offered access to all the communal facilities for putting teachers' proposals into practice. Thanks to students, teachers, and authorities, the focus group achieved its aim of collectively planning an EE programme. Teachers and authorities adapted the content of the EE programme of San Juan Nuevo (Barraza \& RuizMallén, 2007) to Ixtlan forestry enterprise activities; they decided, for example, to include the ecotourism enterprise in the EE programme. The EE programme content also reinforced the ecological concepts included in the preparatory school curriculum, such as ecosystem, biological conservation, and resource management. The programme consisted in eight sessions to be taught during a two-month period. Teachers, forest workers, and local authorities coordinated the whole 
programme. They used a variety of teaching methods such as fieldtrips, lectures, practical fieldbased exercises, and group discussion-based workshops (Table 2).

\section{INSERT TABLE 2 ABOUT HERE}

The programme was first taught during April and May 2005. At this time, the programme was taught in the afternoons or during weekends because it was not yet formally included into the preparatory school curriculum. A total of 40 people were involved in this first experience: 33 students, two teachers, and five forestry and ecotourism enterprises' workers.

As a consequence of the success of the first experience, teachers and local authorities collaborated in implementing the EE programme again during the next semester [August and September 2005] with a similar rate of students' and teachers' participation. This second time around, the programme was modified by teachers and communal authorities to reflect students' requests for additional sessions on community water availability and waste management and treatment. Those particular sessions reflected the fact that the Municipality and the communal authorities have responsibilities for promoting sound environmental policies that affect all citizens.

In 2006, the state-wide Department of Education decided to include the EE programme into Ixtlan's preparatory science curriculum as a part of the Ecology module which is taught in the $2^{\text {nd }}$ year. More than a hundred of students, three teachers, seven forestry and ecotourism workers, and two municipal workers participated in the development of this EE programme in 2005 and 2006.

\section{Discussion}

In Mexico, most existing EE experiences have been developed in non-formal educational contexts. This article documents the participatory process of the creation of a formal EE 
programme in Ixtlan preparatory school. The main merit of the EE programme just presented lies in that it was completed in the same way it was planned: voluntarily and collectively. The methodology used, particularly the focus group, was very useful for action research objectives. The focus group helped to explore preparatory school teachers', students', and authorities' perceptions and opinions about promoting learning contextualisation. It also helped to provide students and teachers to become more invested in developing teaching-learning skills on EE. Since focus groups are based on group interaction (Kitzinger, 1995), by using this method all participants were encouraged to talk to one another, exchange opinions, and collectively construct an EE programme focused on local natural resources management.

The process was possible despite Mexican educational constraints, as identified in semistructured interviews with Ixtlan's preparatory school teachers. The success of the programme in terms of durability is mostly a consequence of local people empowerment. Since teachers and students were able to take decisions about the whole programme (i.e., topics, schedule, and lectures) they could adapt it to their interests, possibilities, and to community and school resources, so they were both able and motivated to continue with the EE experience. This programme can be taken as an experience of how active participation helps individuals to identify and to reflect in their own responsibility for constructing an EE programme collectively.

Finally, the role of researchers might have also contributed to the success of the EE programme planning. Researchers worked as participants rather than as mere observers. The consensus achieved by students, teachers, and local authorities regarding the creation of the EE programme was partially possible because the researchers promoted the focus group where participants could discuss it. Since the action research framework promotes participation, EE researchers should involve themselves in community discussions to support and encourage people to participate in EE programmes planning. 
The main limitation that has been identified in this educational research experience relates to the inclusiveness of the focus group. The focus group did not include all the preparatory school students because the method requires a limited number of participants. Only the most interested students in environmental issues could participate in designing Ixtlan programme's contents and activities. Although focus group reduces actors' participation in programme planning, results shown that it is an effective method to make decisions on programme construction.

\section{Conclusions}

This case study shows that it is possible to plan a successful formal EE programme with the participation of students, teachers, and school and communal authorities. In addition, this study also led to the construction of a pertinent higher level curriculum relevant to Ixtlan's current reality. In this sense, this case study contributes to consolidate the action research framework in EE research by accomplishing the pedagogical aim to transform, through teacher reflexivity, the science school curriculum towards participative educational experiences. This, as Elliot identified as long ago as 1994, meets an identified gap in existing education research - a gap that we are pleased to help close.

Based on the results of this research, we propose five key conditions for planning contextualised and long-term EE programmes in formal education systems:

- Self-empowerment. Support community members to coordinate the design and implementation of the EE programme, and to control the entire programme planning while being free from external institutional interventions.

- Stability. Encourage school teachers and local authorities to establish formal agreements which assure their future collaboration. 
- Adaptability. Guide stakeholders in using novel teaching techniques that allow changing the content to be appropriate with new local situation while maintaining the intention of the session (i.e. field trips to teach different forestry problems: fires, diseases, deforestation).

- Involvement. Promote feedback on learning, both to the teacher and to the students themselves, by encouraging teachers to adopt participatory teaching techniques.

- Reflection. Improve environmental knowledge and values acquisition, as well as students' discussion and reflection on the local environmental situation and solutions for improving local natural resource management.

\section{References}

Aguilera, S., Rodríguez, M. A., \& Silva, M. (2006). Plataforma Educativa 2006. Educación Básica. Mexico, Observatorio Ciudadano de la Educación..

Antironi, C., \& Rausser, G. (2007). Collective choice and community forestry management in Mexico: an empirical analysis. Journal of Development Studies, 43(3), 512-536.

Ballantyne, R., Fien, J., \& Packer, J. (2001). School environmental education programme impacts upon student and family learning: a case study analysis. Environmental Education Research, 7, 23-27

Barraza, L. (2000). Educar para el futuro: En busca de un nuevo enfoque de investigación en educación ambiental. In Memorias Foro Nacional de Educación Ambiental (pp. 253260). Mexico, Universidad Autónoma de Aguascalientes, Secretaría de Educación Pública y Secretaría de Medio Ambiente, Recursos Naturales y Pesca. 
Barraza, L. (2001). Environmental education in Mexican schools: A review at primary level. The Journal of Environmental Education, 32, 31-36.

Barraza L., \& Waldorf, R. A. (2002). Environmental education: A comparison between English and Mexican children. Environmental Education Research, 8, 171-176.

Barraza L., \& Cuarón, A. (2004). How values in education affect children’s environmental knowledge. Journal of Biological Education, 39(1), 18-23.

Barraza, L., \& Ruiz-Mallén, I. (2007) Estrategia participativa de investigación educativa socio ambiental con jóvenes de una comunidad forestal mexicana (pp. 231-246). In A. Curiel (Ed.), Tipos de investigación en y para la salud ambiental y la educación ambiental. Mexico, Universidad de Guadalajara y Universidad de Granada.

Comunidad de Ixtlan de Juarez. (1999). Communal Statue of Ixtlan de Juarez. Mexico, Ixtlan de Juarez.

Duit, R. (1991). On the role of analogies and metaphors in learning science. Science Education, $75,649-672$.

Elizondo A., Flores, L. A., \& González, Y. (2007). Programa Ciencia en Familia: en la promoción de educación ambiental. Cuba, VI Congreso de Educación Ambiental.

Elliot, J. (1994). Research on teachers' knowledge and action research. Educational Action Research, 2(1), 133-137.

Hart, R. A. (1997). Children's Participation: the theory and practice of involving young citizens in community development and environmental care. London, Earthscan Publication Ldt.

Hart, P., \& Nolan, K. (1999). A critical analysis of research in environmental education. Studies in Science Education, 34, 1-69.

URL: http://mc.manuscriptcentral.com/tsed Email: editor_ijse@hotmail.co.uk 
Hodson, D., \& Bencze, L. (1998). Becoming critical about practical work: changing views and changing practice through action research. International Journal of Science Education, 20(6), 683-694.

Gayford, C. (1993) Discussion-based group work related to environmental issues in science classes with 15-year-old pupils in England. International Journal of Science Education, 15(5), 521-529.

García-Ruiz, M., \& Calixto Flores, R. (2006). Educación ambiental para un futuro sustentable. Mexico, Universidad Pedagógica Nacional.

Kemmis, S., \& Carr, W. (1988). Teoría crítica de la enseñanza. La investigación-acción en la formación del profesorado. España, Martínez Rica.

Kitzinger, J. (1995). Introducing focus groups. British Medical Journal, 311, 299-302.

Palmer, J. (1998). Environmental Education in the 21st. Century. London, Routledge.

Peralta, M. V. (1996). Currículos educacionales en América Latina. Su pertinencia cultural. Chile, Editorial Andrés Bello.

Reinfried, S. (2004). Do curriculum reforms affect classroom teaching in Geography? The case study of Switzerland. International Research in Geographical and Environmental Education, 13(3), 239-250.

Ruiz-Mallén, I., \& Barraza, L. (2006). Environmental learning in adolescents from a Mexican community involved in forestry. International Social Science Journal, 189, 513 -524.

Ruiz-Mallén, I., Barraza, L., Bodenhorn, B., \& Reyes-Garcia, V. (2009). School and local environmental knowledge, what are the links? A case study among indigenous adolescents in Oaxaca, Mexico. International Research in Geographical and Environmental Education, 18(2), 82-96. 
Sauvé, L. (1999). La educación ambiental, entre la modernidad y la posmodernidad. Tópicos en educación ambiental, 1(2), 7-27.

Snook, L. (1997). Uso, manejo y conservación forestal en México. In L. Paré, D. Bray, J. Burstein, \& S. Martínez, Semillas para el cambio en el campo (pp. 19-36). Mexico, Instituto de Investigaciones Sociales-Universidad Nacional Autónoma de México, Soc. de Solidaridad “Sansekan Tinemi” y Servicios de Apoyo Local al Desarrollo de Base en Mexico.

Strauss, A. L. (1987). Qualitative analysis for social scientists. Cambridge, Cambridge University Press.

UNESCO. (1994). Education for all, summit of nine preparatory population countries. Final report. Paris, UNESCO.

Taylor, P., \& Mulhall, A. (2001). Linking learning environments through agricultural experience - enhancing the learning process in rural primary schools. International Journal of Educational Development, 21, 135-148.

Warwick, P., \& Siraj-Blatchford, J. (2006). Using data comparison and interpretation to develop procedural understandings in the primary classroom: Case study evidence from action research. International Journal of Science Education, 28(5), 443-467.

Watts, M., \& Jofili, Z. (1998). Towards critical constructivist teaching. International Journal of Science Education, 20(2), 173-185. 
Figure 1. Network diagram on teachers' opinions about preparatory school curriculum contextualisation. 
Note: Number of teachers' opinions in each category in parenthesis

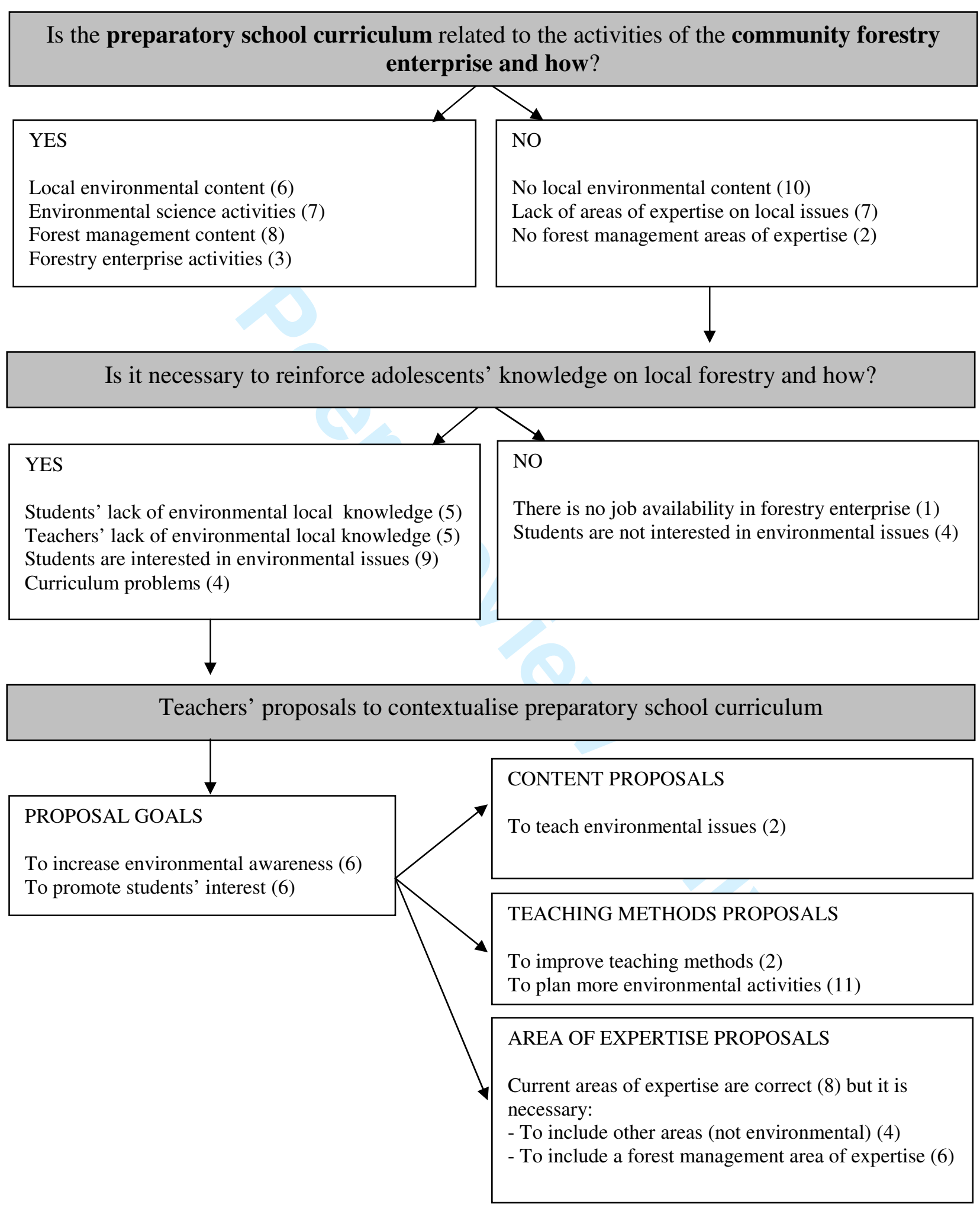


Table 1. Preparatory school teachers' semi-structured interview questionnaire.

\section{Name: $\quad$ Subject: School year/s taught: \\ A. Is the curriculum related to the activities of the community forestry enterprise and how?}

1. What do you think about Ixtlan preparatory school curricula?

2. Do you think that preparatory school areas of expertise are useful for adolescents in terms of gaining a job in Ixtlan's community and region in the future? Would you eliminate an existing area of expertise? Would you add a new one?

3. Would you add or eliminate any subject from the preparatory school curriculum? Which one would you add or eliminate? Why?

4. Do you think that preparatory school subjects include regional and local contents? Which are the subjects that include them? Do you think its enough with these subjects? Why?

5. Do you think that environmental topics are included in preparatory school curriculum? What are the subjects that include environmental topics?

6. Do you talk about the communal forestry enterprise in your classes? Do you talk about the community? Do you talk about forest resources? Why do you talk (or not) about them? What do you explain about them? Would you like to include environmental contents in the subject/s you teach?

\section{B. Is it necessary to reinforce adolescents' knowledge on local forestry and why?}

7. Do you think that preparatory school students should know more about environmental issues from their community, including the forestry enterprise? Why? 8. What do you propose for incorporating forestry enterprise activities in preparatory school curriculum?

9. Does the subject you teach incorporate environmental topics? Which ones?

10. Do you think students are interested in learning about environmental topics?

11. Do students ask you about environmental topics? What do they ask?

12. Do you think students are interested in knowing more about forestry enterprise? 
Table 2. Ixtlan preparatory school EE programme.

\begin{tabular}{|c|c|c|c|}
\hline Session & Topic & Lecturer & Method \\
\hline 1 & $\begin{array}{l}\text { Ixtlan's history and Ixtlan forestry } \\
\text { enterprise' foundation and evolution }\end{array}$ & $\begin{array}{l}\text { Forest enterprise } \\
\text { Manager }\end{array}$ & Lecture \\
\hline 1 & $\begin{array}{l}\text { San Juan Nuevo forestry enterprise and the } \\
\text { cooperation between Ixtlan and San Juan }\end{array}$ & Sociologist & Lecture \\
\hline 2 & $\begin{array}{l}\text { Forestry enterprise departments' functions } \\
\text { and forest management plans }\end{array}$ & Forest engineer & $\begin{array}{l}\text { Visit to Forest } \\
\text { Enterprise } \\
\text { Administration }\end{array}$ \\
\hline 3 & $\begin{array}{l}\text { The forest ecosystem, and forest fires and } \\
\text { diseases control methods }\end{array}$ & Forest engineer & Lecture \\
\hline 4 & $\begin{array}{l}\text { Tree nurseries and plantations as strategies } \\
\text { for environmental conservation and } \\
\text { development. }\end{array}$ & $\begin{array}{l}\text { Forest enterprise } \\
\text { worker }\end{array}$ & $\begin{array}{l}\text { Visit to tree } \\
\text { nurseries and } \\
\text { plantations }\end{array}$ \\
\hline 5 & The sawmill production areas & Forest engineer & Visit to sawmill \\
\hline 6 & $\begin{array}{l}\text { The role of ecotourism in Ixtlan } \\
\text { environmental conservation and economy }\end{array}$ & $\begin{array}{l}\text { Ecotourism } \\
\text { enterprise } \\
\text { Manager }\end{array}$ & $\begin{array}{l}\text { Visit to ecotourism } \\
\text { enterprise }\end{array}$ \\
\hline 7 & $\begin{array}{l}\text { Students' proposal of planning a school } \\
\text { garden for their preparatory school }\end{array}$ & Teachers & $\begin{array}{l}\text { Group discussion- } \\
\text { based }\end{array}$ \\
\hline 8 & $\begin{array}{l}\text { Future collaboration activities planning } \\
\text { between preparatory school and community }\end{array}$ & $\begin{array}{l}\text { Preparatory } \\
\text { school and local } \\
\text { authorities }\end{array}$ & Collective dynamic \\
\hline
\end{tabular}

